\section{Australia set to double medical} research spending

Sydney. Government plans to double funding for biomedical research in Australia may be accelerated, following the publication of a report that strongly criticizes the funding and administration of the National Health \& Medical Research Council (NHMRC), the main source of funds for such work.

The government had already promised in the last election campaign to double its spending on medical research by the end of the decade. Hints that the date for achieving this goal may be brought forward have now been made by Graham Richardson, the Minister for Health.

Commenting earlier this month on the NHMRC review, Richardson said it was "hazardous" to make promises in advance of discussions about the government's annual budget. But he added that the next annual budget, to be announced in September, would go very close to achieving that promise "within the next four to five years".

The review of the council, which advises the government on the allocation of $\$ \mathrm{~A} 112$ million (US\$80 million) in grants each year, was carried out by John Bienenstock, dean of health sciences at McMaster University in Ontario, Canada.

Bienenstock points out in his report that Australia spends less on medical research, both as a proportion of gross domestic product and as a proportion of the amount spent on health care, than any other country belonging to the Organization for Economic Cooperation and Development (OECD).

This low level of support is compounded by the lack of private sector support. Bienenstock also strongly criticizes the small size of NHMRC's secretariat in comparison to the value of the grants it administers. A lack of administrative support is the major factor in the council's failure to develop a strategic plan for health research, he says, or to address national health problems in particular areas, notably Aboriginal health.

His report concludes that the secretariat's support had lagged so far behind the growth in the council's activities that it "seriously jeopardizes the reputation and effectiveness of the NHMRC".

Ian McCloskey, chairman of the council's medical research committee, says that Bienenstock's report - including its comments on the size of the council's secretariat -- was welcome. He said the amount spent on the secretariat was equivalent to 1.7 per cent of the total amount of grants allocated, and that the equivalent bodies responsible for medical research funds in other countries usually received between four and five per cent of the total value of research grants.

Mark Lawson

\title{
EMBL spreads future planning in bid to keep Italy on board
}

Munich. A special meeting of the European Molecular Biology Laboratory (EMBL) council last week took two steps that it hopes will help to persuade Italy to reverse its decision to resign from the laboratory at the end of this year.

The council agreed that Fotis Kafatos, EMBL's new director, should involve scientists from its member states more closely in the design of future science programmes. It also endorsed the laboratory's enhanced efforts to hire more staff from southern Europe.

Italy's resignation was announced at the end of December, and followed complaints over several years that it has relatively few staff positions at EMBL's laboratory in Heidelberg, despite paying 16 per cent (around DM10 million) of the laboratory's annual budget (see Nature 366, 604; 1993).

Kafatos had hoped to head off Italy's move by announcing a new programme under which research groups will be set up by EMBL in various countries in Southern Europe. Everyone, including the Italians, seemed satisfied, and the EMBL council meeting last December approved the setting up of four such groups in Italy, and one in Spain, for a five-year period from 1995.

But within weeks, Italy carried out its threat to resign, claiming that commitment to the regional groups was not as extensive as hoped. The resignation letter, however, made clear that Italy would be willing to rejoin if it received a better return on its contributions to the laboratory.

Now, in a move designed to broaden consultation over the development of EMBL's scientific programmes and also meet criticism of past procedures, the next five-year plan - to run from 1996 to 2000 - will be circulated in draft form to member states for discussion with their national scientific communities. Comments and counter-proposals will be considered by Kafatos before the plan is finalized, it is hoped by the middle of next year.

In addition, under a recruitment scheme introduced nearly a year ago and formally endorsed by council last week, a laboratory search committee will actively seek applications for its scientific posts from all parts of Europe, including those that seem to have been neglected in the past.

The council published a declaration stating that there will be "no question of compromising quality or introducing quotas". But, according to Steve Fuller, a senior scientist, the relatively high turnover of staff at EMBL, averaging four to five group leaders each year, combined with the efforts of the search committee, means that the balance of staff scientists "could be changed quite quickly".

Italy is also taking steps to find out how much it is to blame for its underrepresentation at EMBL. Many Italian scientists complain that one reason is that young researchers are discouraged from spending long periods gaining experience abroad, as they are in danger of losing important contacts (see Nature 367, 590; 1994). An internal inquiry has been set up by the research minister, Umberto Colombo, to look into the situation, assisted by Italian members of the

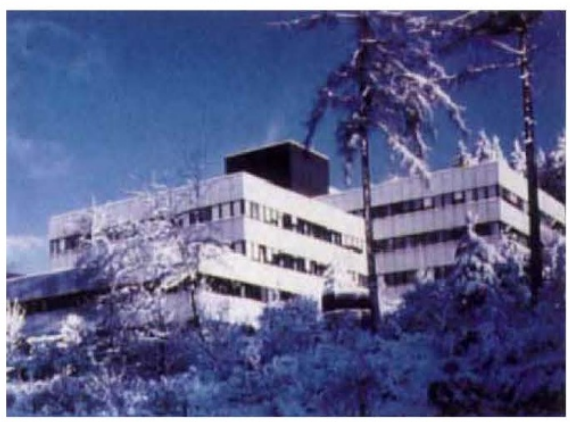

Cold prospects: EMBL at Heidelberg.

European Molecular Biology Organization (EMBO).

EMBL is also taking a critical look at itself, and is preparing an analysis of the past 20 years to identify its successes and failures, in order to develop a more effective long-term role.

Uncertainty hangs over EMBL's future plans until Italy decides whether to withdraw its resignation. Last week, the EMBL council approved a 2.1 per cent increase in this year's budget to DM67.4 million, of which Italy will pay DM10.7 million. But the laboratory cannot begin to draft a budget for 1995, the last year of its current five-year plan, unless it knows whether Italy is definitely in or out.

At present, EMBL is proceeding on the assumption that Italy will stay in the fold. Preparations for all five of the new regional groups are going ahead, and the planned consultations on the next five-year plan will include Italy.

In case Italy does leave, however, Kafatos has already asked senior scientists at the laboratory to make savings in their 1994 budget totalling about a third of Italy's contribution, primarily by delaying the replacement of equipment and certain categories of staff, to help pay the deficit in 1995.

The 14 remaining member states will be asked to provide the rest to make up the missing budget. Salary rises for this year have been kept down to 1.6 per cent, rather than the expected 3.5 per cent. "But no-one is complaining about wage rises in the current climate," says Fuller. Alison Abbott 